\title{
Reproductive effort of Pacific oysters: A trait associated with susceptibility to summer mortality
}

\author{
Arnaud Huvet ${ }^{\mathrm{a},{ }^{*}}$, Julien Normand ${ }^{\mathrm{a}, \mathrm{b}}$, Elodie Fleury ${ }^{\mathrm{a}}$, Virgile Quillien ${ }^{\mathrm{a}}$, Caroline Fabioux $^{\mathrm{c}}$ and Pierre \\ Boudry ${ }^{a}$
}

\author{
a Ifremer, UMR 100 Physiologie et Ecophysiologie des Mollusques Marins, Centre de Brest, BP 70, 29280 \\ Plouzané, France \\ ${ }^{\mathrm{b}}$ Ifremer, Laboratoire de Génétique et Pathologie, 17390 La Tremblade, France \\ c Laboratoire des Sciences de I'Environnement Marin, UMR CNRS 6539, IUEM-Université de Bretagne \\ Occidentale, 29280 Plouzané, France
}

\author{
*: Corresponding author: A. Huvet, Tel.: + 332982246 93; fax: + 3329822 46 53, email address : \\ ahuvet@ifremer.fr
}

\begin{abstract}
:
Summer mortality of the Pacific oyster Crassostrea gigas is the result of a complex interaction between oysters, their environment and their pathogens. The physiological status of an oyster, especially its reproductive status, is suspected to play a significant role in the outcome of this interaction. As genetic variability exists for susceptibility to summer mortality, resistant (R) and susceptible (S) oyster lines were produced using a divergent selection scheme. The present paper reports a histological study on gonad area, which is representative of reproductive effort, in randomly chosen five $\mathrm{R}$ and five $\mathrm{S}$ oyster lines. The $\mathrm{R}$ lines showed a significantly lower gonad area than the $\mathrm{S}$ lines $(P<0.001)$, with an estimated mean difference of $12.5 \%$, whereas, taken together, $R$ and $S$ lines showed a similar distribution of gametogenic stages when sampled. Considering the lines separately, the significant difference in gonad area went up to $24 \%$ between $\mathrm{R}$ and $\mathrm{S}$ lines. The present data confirm and strengthen the negative correlation between reproductive effort and resistance to summer mortality observed in previous studies. Summer mortality of $C$. gigas in France could, therefore, be partly due to a physiological disorder and metabolic disturbance in oysters associated with their reproductive effort. This does not, however, imply a direct link between the cost of reproduction and mortality because other causal factors, such as pathogenic agents, could be the primary causal factors.
\end{abstract}

Keywords: Bivalve mollusc; Crassostrea gigas; Reproduction; Selected lines; Summer mortality 


\section{Introduction}

Significant mortality of the Pacific oyster Crassostrea gigas has been reported to occur during the summer months in several countries and is a major concern for oyster aquaculture. The multidisciplinary project "Morest", set up to study the causes of summer mortality in France, concluded that this phenomenon is multifactorial, resulting from a complex interaction between oysters, their environment and opportunistic pathogens (Samain and McCombie, 2008).

The physiological status of oysters is suspected to play a major part in these interactions, with reproduction, energy and defence as the main contributing factors (Samain et al., 2007). Due to the high reproductive allocation in many marine bivalves, gametogenesis is suspected to be a period of intensive physiological change because most of the energy acquired is used for the production of gametes (Soletchnik et al., 1997 and Royer et al., 2008 for oyster; Myrand et al., 2000 for mussel). In oysters, the relationship between gametogenesis, energy and the mortalities was first investigated at the population level in Japan (Koganezawa, 1974; Mori, 1979), where it was concluded that summer mortality was due to a "physiological disorder and metabolic disturbance derived by heavy gonad formation and massive spawning under high water temperature and eutrophication" (Koganezawa, 1974). Experimental studies in the USA supported these conclusions, illustrating the implication of gonad maturation and loss of carbohydrate reserves in summer mortality (Perdue et al., 1981).

A significant genetic basis was demonstrated for variation in resistance to summer mortality in the USA (Hershberger et al., 1984) and France (Dégremont et al., 2005), and high heritability was estimated for this trait (Dégremont et al., 2007). Due to this genetic basis, it has been possible to select oyster lines showing contrasted levels of resistance to summer mortality: resistant "R" or susceptible "S" lines (Boudry et al., 2008). Gametogenesis and spawning time of $R$ and $S$ oysters from successive generations was studied in different rearing sites along the French coast (Huvet et al., 2008). In some cases, S oysters invested more in reproduction than $\mathrm{R}$ oysters suggesting a negative relationship between survival and reproductive effort, originally reported in Samain et al. (2007) for the second generation of $R$ and $\mathrm{S}$ lines. S oysters also displayed partial spawning and remained with unspawned gametes for a longer time, while R oysters had high synchronous spawning (Samain et al., 2007). However, such reproductive differences were not consistent between years or sites. This might be due to an interaction between environment and genetic determinism for reproductive characters, as discussed in Ernande et al. (2004).

The present study aimed to compare the fifth-generation of $\mathrm{R}$ and $\mathrm{S}$ selected lines for their reproductive effort by making a histological study of the gonad area under controlled conditions. The semi-quantitative histology method used, coupling traditional histology with image analysis, made it possible to evaluate the proportion of gonadic tissue (Royer et al., 2008). The relationship between reproductive pattern of oysters and their ability to survive during the summer is discussed in the light of the hypothesis that the trade-off between survival and reproductive effort could arise from a energetic conflict between physiological functions within the oyster.

\section{Material and Methods}

\subsection{Biological material}

Inbred lines, selected to present high or low resistance to summer mortality, had already been produced following procedures described in detail by Boudry et al. (2008). Briefly, divergent selection was first performed based on 3 sets of 24 full-sib families of first generation (G1) (Dégremont et al., 2005; 2007) and 12 of these families showing contrasted 
genetically-based resistance to summer mortality were chosen to serve as genitors for the next generation. Within-family crosses were then performed over two successive generations using a mean number of 25 (second generation: G2) or 12 (third generation: G3) males and females, with the objective of maintaining the genetic characteristic of each line together with moderate inbreeding (for more details see Boudry et al., 2008). The fourth generation (G4) was produced in 2005 by crossing third generation individuals within each ("G3c2") line to generate 24 inbred G4R and G4S lines according to the crossing designs presented in Tables 1 and 2, respectively. An average of 10 males and 16 females were used for each parental group and crosses were made in both directions (males $x$ females and females $x$ males).

For each G4R and G4S batch, 500 oysters were kept at the Ifremer nursery in Bouin (Vendée, France), isolating them from mortality risks. Sixty 2-year-old oysters per batch were then transferred at stage 1 (according to the reproductive scale of Steele and Mulcahy, 1999) in March 2007 to the La Tremblade hatchery and conditioned for 3 months with suitable conditions for germ cell maturation. Briefly, oysters were placed in experimental raceway in $20 \mu \mathrm{m}$-filtered running seawater at $19 \pm 1.0^{\circ} \mathrm{C}$ and fed with a mixed diet of four microalgae following the standardized protocols established for maturation (Robert and Gérard, 1999). At ripeness (stage 3 ), around 20 oysters per batch were collected for histological analysis from each of 5 R (cR2, cR3, cR6, cR10, cR11; Table 1) and 5 S (cS2, cS3, cS6, cS10, cS11; Table 2) lines. Theses 10 lines were the lines available from among the 24 produced. Indeed, progenitors of the 14 other G4 lines were used to generate the G5R and G5S lines (Lapègue S., Pers. Comm.). These 10 lines were not chosen to reflect differences in reproductive characteristics and can be considered as randomly selected.

\subsection{Semi-quantitative histology}

The percentage surface occupied by the gonad, compared to the total surface of the visceral mass, was estimated on a median section as described in Fabioux et al. (2005). For each sample, a 3-mm cross section of the visceral mass was excised in front of the pericardic region and immediately fixed in Davidson's solution (Shaw and Battle, 1957) at $4{ }^{\circ} \mathrm{C}$ for $48 \mathrm{~h}$. Sections were dehydrated in ascending ethanol solutions, cleared with histosol and embedded in paraffin wax. Sections of $5 \mu \mathrm{m}$ were cut, mounted on glass slides and stained with Harry's hematoxylin-Eosin Y (Martoja and Martoja-Pierson, 1967). Slides were then examined under a light microscope to determine the sex and gametogenic stage according to the reproductive scale of Steele and Mulcahy (1999). Only three different stages were observed and considered in the present study:

for female,

- Stage 1 (developing early active) Oogonia arising from stem cells along the follicle; no free oocytes. Connective tissue is very abundant.

- Stage 2 (developing late active) Free and attached oocytes present with distinct nuclei that stain lighter than the cytoplasm.

- Stage 3 (ripe) Free oocytes with distinct nucleus and nucleolus.

for male,

Stage 1 (developing early active) Many small follicles; spermatogonia and spermatocytes numerous, no spermatozoa.

Stage 2 (developing late active) Follicle cells contain predominantly spermatids and spermatozoa; characteristic swirling pattern of spermatozoa, with tails toward follicle lumen, in centre of follicle.

Stage 3 (ripe) Inter follicular tissue and germinal epithelium are inconspicuous. Follicles filled with spermatozoa oriented with tails to follicle lumen forming characteristic swirling pattern that completely fills follicle.

Percentage areas of gonadic tubules, conjunctive tissue and digestive gland were then determined on each histological section. Slides were scanned with a digital scanner (hp scanjet $7400 \mathrm{c}$ ) and the images saved in *.TIFF format. Tissue areas were then measured 
using image analysis software (Imaq Vision Builder, National Instruments Corp.). Gonad area percentage was estimated as pixel number, from gonad / pixel number on total sections, as described in Fabioux et al. (2005).

\subsection{Statistical analyses}

Statistical analyses were performed using one-way analyses of variance followed by multiple comparison tests with the Tukey's HSD method using STATGRAPHICS software. The percentages (gonad area, survival) were analysed after angular transformation. Comparisons of sex and gametogenic stage distributions between lines were made using Chi-square tests. Sequential Bonferroni adjustment of the $P$-values (Rice, 1989) was used to correct tests comparing gametogenic stage. All the statistical significances were reported at $P<0.05$.

\section{Results}

\subsection{Semi-quantitative histology}

Mean gonadic tissue surface percentages varied from $13.5 \pm 6.7$ to $57.7 \pm 11.9 \%$ for the lines cR2 and cS11, respectively (Figure 1). All together, the R lines showed a significantly lower mean gonad surface area $(35 \pm 18.7 \%)$ than the $S$ batches $(45.9 \pm 15.8 \%)$. Statistical groups were revealed, showing that batches cR2, cR3 and cR10 displayed the lowest gonad surface percentages, whereas batch cS11 followed by cS2, cS3, cR6 and cR11showed the highest gonad surface percentages.

3.2. Gametogenic stages

More than $70 \%$ of the studied oysters, except batches cR2 and cR3, were in stage 3, corresponding to ripeness. Batches CR2 and CR3 showed only 35.7 and $57.1 \%$ stage 3 individuals, but these values are based on a lower number of observations (Table 3 ). All the other animals were in stage 2, corresponding to late germ cell maturation, except for the line cR2 in which 2 animals (i.e. $14.3 \%$ ) were at early gametogenesis (stage 1: developing early active). Lines $\mathrm{CR} 2$ and $\mathrm{CR} 3$ had the most unusual distribution, which was statistically different from the distribution of 7 and 6, respectively, of the other lines (Table 4). All together, the $R$ lines and the $S$ lines showed a similar distribution of reproductive stages (Chi-square $=4.23$; $P=0.12)$.

3.3. Sex-ratio

Pacific oysters are protandrous alternate hermaphrodites. Within batches, the sex-ratio (male/female) varied from 39/61 \% in cR6 to 70/30 \% in cR11. The proportion of males was high in most of the batches (7 out of 10 lines) and only lines cS2, cR3 and cR6 had a high number of females, but with no significant differences between $\mathrm{R}$ and $\mathrm{S}$.

\section{Discussion}

The studied oysters were part of the fourth generation of experimental lines developed to study the genetic and physiological basis of resistance to summer mortality (Samain and McCombie, 2008). R and S lines consistently showed differential susceptibility to summer mortality over these generations (Boudry et al., 2008). This fourth generation was tested in Marennes-Oléron bay (Charente-Maritime, France) during summer 2005. In a similar way to the previous generations, G4 R lines clearly showed lower mortalities (mean $=10 \%$ ) than G4 S lines (47\%), this difference being highly significant. 
Previous generations of $\mathrm{R}$ and $\mathrm{S}$ oysters exhibited differences in their reproductive characteristics (i.e. gametogenesis intensity and spawning behaviour) depending on year and rearing site. Sometimes no differences were observed and can be masked by environmental conditions (Huvet et al., 2008; summarized in Table 5). In our study, G4 lines were conditioned in the hatchery in preparation for the production of the next generation (G5), allowing reproductive allocation to be studied under controlled conditions. When examining the median part of the visceral mass, the percentage surface occupied by the gonad is directly linked to the number and/or size of gametes produced and is therefore representative of reproductive effort (Royer et al., 2008) which corresponds to the proportion of energy allocated to reproduction (Todd \& Havenhand 1983; Normand et al., 2009). Our data clearly demonstrated that, under our experimental conditions, the $\mathrm{R}$ lines had a lower reproductive effort than the $S$ lines. When considering each line separately, a significant difference was observed within $R$ lines: two $R$ lines (cR6, cR11) displayed reproductive effort that was non different to those of the $S$ lines. Interestingly, CR11 had previously been reported to display the worst survival of the G4CR batches (Boudry et al., 2008); the line cR11 being not statistically different from the $S$ lines in terms of survival. Our data showed that CR11 was not statistically different in terms of gonad area either. Taken together, these results suggest that $R$ lines may survive better because they are not as reproductively active as $S$ lines: a result which is in agreement with the negative genetic correlations observed in non-selected ('wild') families between reproductive effort and survival reported by Ernande et al. (2004). As proposed by these authors, this observed 'trade-off' could contribute to maintaining genetic variability in wild oyster populations for these traits. However, this negative correlation between survival and reproduction was only found under low food conditions in this previous study whereas the greatest difference in gametogenesis intensity between $\mathrm{R}$ and $\mathrm{S}$ oysters appears in rich trophic condition (Huvet et al., 2008; the present study). The effect of food on gametogenesis intensity in $\mathrm{R}$ and $\mathrm{S}$ oysters therefore requires further investigation. Additionally, these results also agree with the better survival often reported for triploid oysters (Samain and McCombie, 2008), as triploid oysters are commonly much less fertile than their diploid counterparts (Shpigel et al., 1992; Normand et al., 2008). As was previously suggested following the summer mortality phenomena observed in Japan (Koganezawa, 1974; Mori, 1979), a physiological disorder and metabolic disturbance of C. gigas caused by heavy gonad formation was clearly partially responsible for the summer mortality observed in France during the Morest project (2000-2006). This phenomenon may enhance the susceptibility of oysters to pathogens, which are often reported to be associated with summer mortality events (Renault et al., 1995; Le Roux et al., 2002; Sauvage et al., 2009). The high energetic demand due to gametogenesis could result in an energetic imbalance that leads to decreased defences against pathogens during the reproductive season. However, Pouvreau et al. (2006) assumed minimal costs of maintenance for gonadic tissue in the $C$. gigas dynamic energy budget model. Alternatively, this observed association between reproductive effort and increased susceptibility to summer mortality could result from reduced immune capacities of haemocytes. Reduced phagocytosis activity of haemocytes has previously been reported during oyster gametogenesis (Delaporte et al., 2006). Similarly, a reduction of "haemolymph profile" (i.e. cells are fewer, smaller and less complex; phagocytosis and phenoloxidase activity are low, associated with high basal reactive oxygen species production) was observed during gonad maturation in abalone, with consequences in terms of susceptibility to the bacteria Vibrio harveyi (Travers et al., 2008). Finally, environmental conditions that promote both pathogens and oyster gonad development represent a potential cause of mortality episodes.

The differential selection of $\mathrm{R}$ and $\mathrm{S}$ lines for mortality resistance appeared to be associated with reproductive effort (estimated by gonad occupation). It might also be associated with the temporal dynamics of gametogenesis, as these two traits are known to be closely correlated (Royer et al., 2008). For the cR2 and cR3 lines, displaying low gonad area, less than $50 \%$ of the oysters were fully mature at the point of sampling, whereas 75 to $100 \%$ of the other batches contained fully mature oysters. Slower gametogenesis is therefore suspected for these two R lines, partly explaining why low gonad areas were observed. This is especially 
suggested for CR2 that displayed a very low gonad area (13.5\%) and a high variability in stage repartition. Indeed, two modal classes of oocyte diameter were observed in C. gigas females during what Lango-Reynoso et al. (2000) called the growing phase which corresponds to the gametogenic stages 2 and 3 . Additional effects of gametogenesis timing cannot therefore be excluded for the cR2 and cR3 lines. This assumption does not alter an effect suspected from gonad occupation which takes into account number and size of gametes to estimate the reproductive effort of oysters. Furthermore, cR10, displaying one of the lowest gonad occupation, had more than $90 \%$ of fully mature oysters as well as S lines.

Finally, no significant effect was observed on the sex-ratio. Sex-ratio was not significantly unbalanced and no significant difference of sex repartition was observed between the two types of lines. To date, no significant effect of the sex was shown for summer survival. This was first argued by some genetic correlations in Ernande et al. (2004) and then phenotypically observed in Samain and McCombie (2008). All together, these results support the absence of direct effect of the gender developed by an oyster during a reproductive season on its further ability to survive during summer. This is clearly in agreement with the similar reproductive effort and costs suggested in males and females of the oyster Sydney rock oyster Saccostrea glomerata (Honkoop, 2003).

In terms of spawning behaviour, no partial spawning was suspected in the present data based on the histological examination. The partial spawning previously observed in the $S$ oysters, especially in experimental conditions at the Argenton hatchery where they can be observed easily (Table 5; Huvet et al., 2008), constitute an other possible starting point for further research to document the association between reproduction and summer mortality. To date, a clear relationship was established between the spawning period and abalone disease susceptibility to Vibrio harveyi infection (Travers et al., 2008). In mussels, Myrand et al. (2000) reported the importance of a second, and major mussel spawning on the appearance of summer mortalities (Myrand et al., 2000).

Finally, comparative genomic will be helpful to support the reproductive effort as one of the physiological determinant of resistance to summer mortality (Fleury et al, 2008, 2010).

\section{Acknowledgements}

The authors are indebted to J.F. Samain as the director and coordinator of MOREST, a multidisciplinary network created to investigate the origins of Crassostrea gigas summer mortality. The authors are grateful to J. Moal and J.Y. Daniel for their assistance and to all the staff of the La Tremblade station, especially Stéphanie Grouhel for providing her technical assistance. We thank Helen McCombie for improving the English.

\section{References}

Boudry, P., Dégremont, L., Haffray, P., 2008. The genetic basis of summer mortality in Pacific oyster spat and potential for improving survival by selective breeding in France. Summer mortality of Pacific oyster Crassostrea gigas, the Morest project. Éd. Ifremer/Quæ, pp 153-196.

Dégremont, L., Bédier, E., Soletchnik, P., Ropert, M., Huvet, A., Moal, J., Samain, J.P., Boudry, P., 2005. Relative importance of family, site and field placement timing on survival, growth and yield of hatchery-produced Pacific oyster spat (Crassostrea gigas). Aquaculture 249, 213-229. 
Dégremont, L., Ernande, B., Bédier, E., Boudry, P., 2007. Summer mortality of hatcheryproduced Pacific oyster spat (Crassostrea gigas). I. Estimation of genetic parameters for survival and growth. Aquaculture 262, 41-53.

Delaporte, M., Soudant, P., Lambert, C., Moal, J., Pouvreau, S., Samain, J.F., 2006. Impact of food availability on energy storage and defense related to hemocyte parameters of the Pacific oyster Crassostrea gigas during an experimental reproductive cycle. Aquaculture 254, 571-582.

Ernande, B., Boudry, P., Clobert, J., Haure, J., 2004. Plasticity in resource allocation based life history traits in the Pacific oyster, Crassostrea gigas. I. Spatial variation in food abundance. J. Evol. Biol. 17, 342-456.

Fabioux, C., Huvet, A., Le Souchu, P., Le Pennec, M., Pouvreau S., 2005. Temperature and photoperiod drive Crassostrea gigas reproductive internal clock. Aquaculture 250, 458-470.

Fleury, E., Fabioux, C., Lelong, C., Favrel, P., Huvet, A., 2008. Characterization of a novel gonad-specific transforming growth factor- $\beta$ superfamily member differentially expressed during the reproductive cycle of the oyster Crassostrea gigas. Gene 410, 187-196.

Fleury, E., Moal, J., Boulo, V., Daniel, J.Y., Mazurais, D., Hénaut, A., Corporeau, C., Boudry, P., Favrel, P., Huvet, A., 2010. Microarray-based identification of gonad transcripts differentially expressed between lines of Pacific oyster selected to be resistant or susceptible to summer mortality. Mar. Biotechnol., in press. DOI: 10.1007/s10126-009-9227-9.

.Hershberger, W. K., Perdue, J. A., Beattie, J. H., 1984. Genetic selection and systematic breeding in Pacific oyster culture. Aquaculture 39, 237-245.

Honkoop, P. J. C., 2003. Physiological costs of reproduction in the Sydney rock oyster Saccostrea glomerata. How expensive is reproduction? Oecologia 135, 176-183.

Huvet, A., Royer, J., Moal, J., Burgeot, T., Lapègue, S., Boulo, V., Nicolas, J.L., Lambert, C., Van Wormhoudt, A., Samain, J.F., 2008. Phenotypic characteristics of « R » and « S » oyster lines, selected for resistance or susceptibility to summer mortality. Summer mortality of Pacific oyster Crassostrea gigas, the Morest project. Éd. Ifremer/Quæ, pp 197-241.

Koganezawa, A., 1974. Present status of studies on the mass mortality of cultured oysters in Japan and its prevention. In: (Ed.), Third U.S.-Japan Meeting on Aquaculture, Tokyo, Japan Journal, 29-34.

Lango-Reynoso, F., Chavez-Villalba, J., Cochard, J.C., Le Pennec, M., 2000. Oocyte size, a means to evaluate the gametogenic development of the Pacific oyster, Crassostrea gigas (Thunberg). Aquaculture 190, 183-199.

Le Roux, F., Gay, M., Lambert, C., Waechter, M., Poubalanne, S., Chollet, B., Nicolas, J.L., Berthe, F.C.J., 2002. Comparative analysis of Vibrio splendidus related strains isolated during Crassostrea gigas mortality events. Aquat. Living Resour. 15, 251-258.

Martoja, R., Martoja-Pierson, M., 1967. Initiation aux techniques de l'histologie animale, Masson et Cie, Paris, 1232 pp.

Mori, K., 1979. Effects of artificial eutrophication on the metabolism of the Japanese oyster Crassostrea gigas. Mar. Biol. 53, 361-369.

Myrand, B., Guderley, H., Himmelman, J.H., 2000. Reproduction and summer mortality of blue mussels Mytilus edulis in the Magdalen Islands, southern Gulf of St. Lawrence. Mar. Ecol. Prog. Ser. 197, 193-207.

Normand, J., Le Pennec, M., Boudry, P., 2008. Comparative histological study of gametogenesis in diploid and triploid Pacific oysters (Crassostrea gigas) reared in an estuarine farming site in France during the 2003 heatwave. Aquaculture 282, 124-129.

Normand, J., Ernande, B., Haure, J., McCombie, H., Boudry, P., 2009. Reproductive effort and growth in Crassostrea gigas: comparison of young diploid and triploid oysters issued from natural crosses or chemical induction. Aquatic Biol. 7, 229-241.

Perdue, J.A., Beattie, J.H., Chew, K.K., 1981. Some relationships between gametogenic cycle and summer mortality phenomenon in the Pacific oyster (Crassostrea gigas) in Washington state. J. Shellfish Res. 1, 9-16.

Pouvreau, S., Bourles, Y., Lefebvre, S., Gangnery, A., Alunno-Bruscia, M., 2006. Application of a dynamic energy budget model to the Pacific oyster, Crassostrea gigas, reared under various environmental conditions. J. Sea Res. 56, 156-167. 
Renault, T., Le Deuff, R.M., Cochennec, N., Chollet, B., Maffart, P., 1995. Herpes-like viruses associated with high mortality levels in larvae and spat of Pacific oysters, Crassostrea gigas: A comparative study, the thermal effects on virus detection in hatcheryreared larvae, reproduction of the disease in axenic larvae. Vet. Res. 26, 539-543.

Rice, W.R., 1989. Analyzing tables of statistical tests. Evolution 43, 223-225.

Robert; R., Gérard; A., 1999. Bivalve hatchery technology : The current situation for the Pacific oyster Crassostrea gigas and the scallop Pecten maximus in France. Aquat. Living Resour. 12, 121-130.

Royer, J., Seguineau, C., Park, K., Pouvreau, S., Choi, K.S., Costil, K., 2008. Gametogenetic cycle and reproductive effort assessed by two methods in 3 age classes of Pacific oysters, Crassostrea gigas, reared in Normandy. Aquaculture 277, 313-320.

Samain, J.F., Dégremont, L., Soletchnik, P., Haure, J., Bédier, E., Ropert, M., Moal, J., Huvet, A., Bacca, H., Van Wormhoudt, A., Delaporte, M., Costil, K., Pouvreau, S., Lambert, C., Boulo, V., Soudant, P., Nicolas, J.L., Le Roux, F., Renault, T., Gagnaire, B., Géret, F., Boutet, I., Burgeot, T., Boudry, P., 2007. Genetically based resistance to summer mortality in the Pacific oyster (Crassostrea gigas) and its relationship with physiological, immunological characteristics and infection process. Aquaculture 268, 227-243.

Samain, J.F., McCombie, H., 2008. Summer Mortality of Pacific Oyster Crassostrea gigas. Ed. Ifremer/Quae, 379pp.

Sauvage, C., Pépin, J.F., Lapègue, S., Boudry, P., Renault T., 2009. Ostreid herpes virus 1 infection in families of the Pacific oyster, Crassostrea gigas, during a summer mortality outbreak: differences in viral DNA detection and quantification using real-time PCR. Virus Res. 142:181-187.

Shaw, B.L., Battle, H.I., 1957. The gross and microscopic anatomy of the digestive tract of the oyster Crassostrea virginica (Gmelin). Can. J. Zool. 35, 325-347.

Soletchnik, P., Razet, D., Geairon, P., Faury, N., and Goulletquer, P., 1997. Ecophysiology of maturation and spawning in oyster (Crassostrea gigas): Metabolic (respiration) and feeding (clearance and absorption rates) responses at different maturation stages. Aquat. Living Resour. 10, 177-185.

Shpigel, M., Barber, B.J., Mann, R., 1992. Effects of elevated temperature on growth, gametogenesis, physiology, and biochemical composition in diploid and triploid Pacific oysters, Crassostrea gigas Thunberg. J. Exp. Mar. Biol. Ecol. 161, 15-25.

Steele, S., Mulcahy, M.F., 1999. Gametogenesis of the oyster Crassostrea gigas in southern Ireland. J. Mar. Biol. Assoc. U.K. 70, 673-686.

Todd CD, Havenhand JN (1983) Reproductive effort: its definition, measurement, and interpretation in relation to molluscan life-history strategies. J. Molluscan Stud. 12, 203-208.

Travers, M.A., Le Goïc, N., Huchette, S., Koken, M., Paillard, C., 2008. Summer immune depression associated with increased susceptibility of the European abalone, Haliotis tuberculata to Vibrio harveyi infection. Fish Shellfish Immunol. 25, 800-808. 
Table 1. Crossing design used to obtain the inbred G4cR batches following divergent selection on Crassostrea gigas spat survival (Samain and McCombie, 2008).

\begin{tabular}{|c|c|c|c|c|c|c|c|c|c|c|}
\hline \multirow[b]{5}{*}{ Male G0 } & \multirow[b]{5}{*}{ Family G1 } & \multirow[b]{5}{*}{$\mathrm{G} 2 \mathrm{C}$} & \multirow{2}{*}{\multicolumn{2}{|c|}{$\begin{array}{l}\text { Males G0 } \\
\text { Family G1 }\end{array}$}} & \multicolumn{2}{|r|}{2} & \multicolumn{2}{|r|}{9} & \multicolumn{2}{|c|}{15} \\
\hline & & & & & F2-5 & F2-8/F2-5 & F9-35 & F9-36 & F15-57 & F15-58 \\
\hline & & & \multicolumn{2}{|c|}{ G2C } & A2 & C2 & $\mathrm{J} 2$ & $\mathrm{O} 2$ & R2 & W2 \\
\hline & & & \multirow{2}{*}{\multicolumn{2}{|c|}{$\mathrm{G} 3 \mathrm{c}^{2}$}} & \multicolumn{6}{|c|}{ Males } \\
\hline & & & & & AA2 & CC2 & $\mathrm{JJ} 2$ & 002 & RR2 & WW2 \\
\hline \multirow{2}{*}{2} & F2-5 & A2 & & AA2 & cR1 & $\begin{array}{c}\text { CR2 } \\
2.9 \pm 1.1\end{array}$ & & & & \\
\hline & F2-8/F2-5 & $\mathrm{C} 2$ & & $\mathrm{CC} 2$ & $\begin{array}{c}\text { CR3 } \\
2.2 \pm 2.0\end{array}$ & cR4 & & & & \\
\hline \multirow[t]{2}{*}{9} & F9-35 & $\mathrm{J} 2$ & Females & $\mathrm{J} J 2$ & & & cR5 & $\begin{array}{c}\text { CR6 } \\
10 \pm 6.5\end{array}$ & & \\
\hline & F9-36 & $\mathrm{O} 2$ & & $\mathrm{OO2}$ & & & CR7 & cR8 & & \\
\hline \multirow{2}{*}{15} & F15-57 & $\mathrm{R} 2$ & & $\mathrm{RR} 2$ & & & & & cR9 & $\begin{array}{c}\text { CR10 } \\
15.6 \pm 6.1\end{array}$ \\
\hline & F15-58 & W2 & & ww2 & & & & & $\begin{array}{c}\text { CR11 } \\
22.2 \pm 14.6\end{array}$ & cR12 \\
\hline
\end{tabular}

Lines studied in the present paper are given in bold. The cumulative mortality, estimated in the field, is given below the names of the studied lines (\%).

Table 2. Crossing design for obtaining the inbred G4cS batches following divergent selection on Crassostrea gigas spat survival (Samain and McCombie, 2008).

\begin{tabular}{|c|c|c|c|c|c|c|c|c|c|c|}
\hline \multirow[b]{5}{*}{ Males G0 } & \multirow[b]{5}{*}{ Family G1 } & \multirow[b]{5}{*}{ G2c } & \multirow{2}{*}{\multicolumn{2}{|c|}{$\frac{\text { Males G0 }}{\text { Family G1 }}$}} & \multicolumn{2}{|r|}{4} & \multicolumn{2}{|c|}{7} & \multicolumn{2}{|c|}{14} \\
\hline & & & & & $\begin{array}{c}\text { F4-16/F4- } \\
15\end{array}$ & F4-15/F4-16 & $\mathrm{F} 7-25$ & $F 7-26$ & F14-54 & $\begin{array}{c}\text { F14-54/F14- } \\
55\end{array}$ \\
\hline & & & G2C & & B2 & Y2 & E2 & L2 & M2 & $\mathrm{P} 2$ \\
\hline & & & \multirow{2}{*}{\multicolumn{2}{|c|}{$\mathrm{G} 3 \mathrm{c}^{2}$}} & \multicolumn{6}{|c|}{ Males } \\
\hline & & & & & BB2 & YY2 & EE2 & LL2 & MM2 & PP2 \\
\hline \multirow{2}{*}{4} & F4-16/F4-15 & B2 & \multirow{6}{*}{ Females } & BB2 & cS1 & $\begin{array}{c}\text { CS2 } \\
46.9 \pm 3.1\end{array}$ & & & & \\
\hline & F4-15/F4-16 & Y2 & & YY2 & $\begin{array}{c}\text { cS3 } \\
49.8 \pm 19.4\end{array}$ & cS4 & & & & \\
\hline \multirow[t]{2}{*}{7} & F7-25 & E2 & & EE2 & & & cS5 & $\begin{array}{c}\text { cS6 } \\
38 \pm 7\end{array}$ & & \\
\hline & F7-26 & L2 & & LL2 & & & cS7 & cS8 & & \\
\hline \multirow{2}{*}{14} & F14-54 & M2 & & MM2 & & & & & cS9 & $\begin{array}{c}\text { cS10 } \\
63.8 \pm 6.8\end{array}$ \\
\hline & F14-54/F14-55 & P2 & & PP2 & & & & & $\begin{array}{c}\text { cS11 } \\
36.9 \pm 4.0\end{array}$ & cS12 \\
\hline
\end{tabular}

Lines studied in the present paper are shown in bold. The cumulative mortality, estimated in the field, is given below the names of the studied lines (\%). 
Table 3. Distribution of gametogenic stage (according to the reproductive scale of Steele and Mulcahy, 1999) and sex in 10 oyster lines, resistant (cR2, 3, 6, 10, 11) or susceptible (cS2, 3, $6,10,11)$ to summer mortality.

\begin{tabular}{cccccccc}
\hline & & \multicolumn{2}{c|}{ Sex } & \multicolumn{3}{c}{ Gametogenic stage } \\
\cline { 3 - 7 } & $\mathrm{n}$ & $\begin{array}{c}\text { female } \\
\%\end{array}$ & $\begin{array}{c}\text { male } \\
\%\end{array}$ & $\begin{array}{c}1: \\
\text { developing } \\
\text { early active } \\
\%\end{array}$ & $\begin{array}{c}\text { 2: developing late } \\
\text { active } \\
\%\end{array}$ & $\begin{array}{c}\text { 3: ripe } \\
\%\end{array}$ \\
\hline cR2 & 14 & 42.9 & 57.1 & 14.3 & 50 & 35.7 \\
cR3 & 14 & 64.3 & 35.7 & 0 & 42.9 & 57.1 \\
cR6 & 21 & 61.9 & 38.1 & 0 & 7.1 & 92.9 \\
cR10 & 21 & 66.7 & 33.3 & 0 & 9.5 & 90.5 \\
CR11 & 20 & 30 & 70 & 0 & 5 & 95 \\
CS2 & 21 & 57.1 & 42.9 & 0 & 28.6 & 71.4 \\
cS3 & 19 & 44.7 & 55.3 & 0 & 10.5 & 89.5 \\
cS6 & 19 & 47.4 & 52.6 & 0 & 21.1 & 78.9 \\
cS10 & 18 & 44.4 & 55.6 & 0 & 5.6 & 94.4 \\
cS11 & 24 & 45.8 & 54.2 & 0 & 0 & 100 \\
\hline
\end{tabular}

$\mathrm{n}=$ number of individuals analysed.

Table 4. Matrix of $P$ values over all the 10 oyster lines for distribution of gametogenic stages using corrected Chi-square tests (above diagonal), with associated statistical significance (below diagonal).

\begin{tabular}{|c|c|c|c|c|c|c|c|c|c|c|}
\hline & cS2 & cR2 & cS3 & cR3 & cS6 & cR6 & cS10 & cR10 & cS11 & cR11 \\
\hline cS2 & & $\begin{array}{c}\text { 7.18E- } \\
06\end{array}$ & 0.0041 & 0.0133 & 0.3173 & $\begin{array}{c}3.70 \mathrm{E}- \\
07\end{array}$ & $\begin{array}{c}5.07 \mathrm{E}- \\
07\end{array}$ & 0.00294 & $\begin{array}{c}9.99 \mathrm{E}- \\
08\end{array}$ & $\begin{array}{c}3.70 \mathrm{E}- \\
07\end{array}$ \\
\hline cR2 & * & & $\begin{array}{c}4.66 \mathrm{E}- \\
06\end{array}$ & 0.2557 & 0.0028 & $\begin{array}{c}1.00 \mathrm{E}- \\
11\end{array}$ & $\begin{array}{c}2.58 \mathrm{E}- \\
11\end{array}$ & $\begin{array}{c}1.78 \mathrm{E}- \\
06\end{array}$ & $\begin{array}{c}9.04 \mathrm{E}- \\
13\end{array}$ & $\begin{array}{c}1.00 \mathrm{E}- \\
11\end{array}$ \\
\hline cS3 & & * & & 0.0003 & 0.2603 & 0.2712 & 0.3173 & 0.6463 & 0.0811 & 0.2712 \\
\hline cR3 & & & * & & 0.0388 & $\begin{array}{c}2.13 \mathrm{E}- \\
08\end{array}$ & $\begin{array}{c}4.87 \mathrm{E}- \\
08\end{array}$ & 0.00015 & $\begin{array}{c}2.34 \mathrm{E}- \\
09\end{array}$ & $\begin{array}{c}2.13 \mathrm{E}- \\
08\end{array}$ \\
\hline cS6 & & & & & & 0.0017 & 0.0023 & 0.0918 & 0.0004 & 0.0017 \\
\hline cR6 & * & * & & * & * & & 0.6276 & 0.4795 & 0.3074 & 1 \\
\hline cS10 & * & * & & * & * & & & 0.3992 & 0.1530 & 0.6463 \\
\hline cR10 & & * & & * & & & & & 0.1530 & 0.3173 \\
\hline cS11 & * & * & & * & * & & & & & 0.2513 \\
\hline cR11 & * & * & & * & * & & & & & \\
\hline
\end{tabular}

* values significant at the $\mathrm{P}<0.05$ level after sequential Bonferroni adjustment.

Table 5. Summary of gametogenesis characteristics of oyster lines resistant or susceptible to summer mortality. Three parameters, acquired by histology in Samain et al. (2007), Samain and McCombie (2008) and the present study, are presented: gonad occupation, temporal 
dynamics of the gametogenesis and spawning. Only significant data are reported (in bold) plus qualitative data of interest (in italics).

\begin{tabular}{|c|c|c|c|c|c|}
\hline \multirow[t]{2}{*}{ Year } & \multirow[t]{2}{*}{ Generation } & \multirow[t]{2}{*}{ Site } & \multirow[t]{2}{*}{ Stage $^{a}$} & \multicolumn{2}{|c|}{ Gametogenesis observation } \\
\hline & & & & occupation dynamics & spawning \\
\hline 2002 & G1 & Auray & adult & $\mathbf{R}<\mathrm{S}$ & partial $^{\mathrm{b}}$ \\
\hline 2003 & G2 & Auray & adult & & \\
\hline 2003 & G2 & Baie des Veys & adult & $\mathrm{R}<\mathrm{S}$ & \\
\hline 2003 & G2 & $\begin{array}{l}\text { Argenton } \\
\text { hatchery, } \\
\text { low food level }\end{array}$ & adult & & partial $^{\mathrm{b}}$ \\
\hline 2003 & $\mathrm{G} 2$ & $\begin{array}{l}\text { Argenton } \\
\text { hatchery, } \\
\text { food level }\end{array}$ & adult & & partial $^{\mathrm{b}}$ \\
\hline 2004 & G3 & Auray & adult & & partial $^{\text {b }}$ \\
\hline 2004 & G3 & Arcachon & adult & & \\
\hline $\begin{array}{l}2007 \\
\text { this study }\end{array}$ & G4 & $\begin{array}{l}\text { La Tremblade } \\
\text { hatchery }\end{array}$ & adult & $\mathrm{R}<\mathrm{S}$ & \\
\hline
\end{tabular}

\section{Figures}

Figure 1. Reproductive effort estimated by the area occupied by the gonad in 10 oyster lines resistant (cR2, 3, 6, 10, 11) and susceptible (cS2, 3, 6, 10, 11) to summer mortality (mean percentage surface occupied by the gonad / total area of the visceral mass \pm standard error). Multiple comparisons were made between lines using Tukey's HSD method at the $5 \%$ level; homogenous groups share letters.

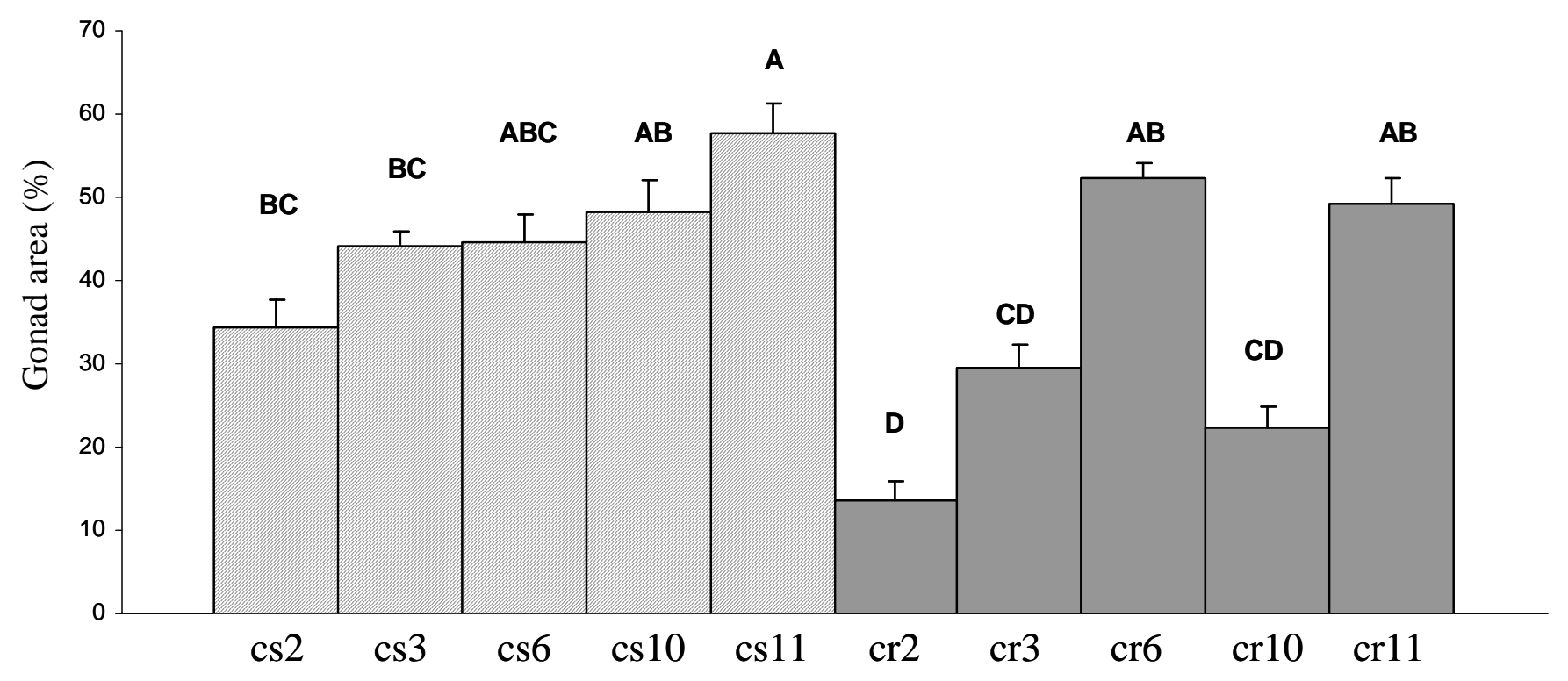

